Article

\title{
Application of UAV and GB-SAR in Mechanism Research and Monitoring of Zhonghaicun Landslide in Southwest China
}

\author{
Bo Liu ${ }^{1}{ }^{\mathbb{D}}, \mathrm{Kun} \mathrm{He}^{1}{ }^{1}$, Mei Han ${ }^{2, *}$, Xiewen $\mathrm{Hu}^{1}{ }^{1}$, Guotao Ma ${ }^{1,3}$ and Mingyang $\mathrm{Wu}^{4}$ \\ 1 Faculty of Geoscience and Environmental Engineering, Southwest Jiaotong University, \\ Chengdu 611756, China; geliubo@my.swjtu.edu.cn (B.L.); hekun@my.swjtu.edu.cn (K.H.); \\ huxiewen@swjtu.edu.cn (X.H.); g.ma.1@warwick.ac.uk (G.M.) \\ 2 School of Mathematics, Southwest Jiaotong University, Chengdu 611756, China \\ 3 School of Engineering, University of Warwick, Coventry CV4 7AL, UK \\ 4 School of Resources and Safety Engineering, Chongqing University, Chongqing 400044, China; \\ wmy@cqu.edu.cn \\ * Correspondence: hanmei@home.swjtu.edu.cn
}

check for updates

Citation: Liu, B.; He, K.; Han, M.; $\mathrm{Hu}$, X.; Ma, G.; Wu, M. Application of UAV and GB-SAR in Mechanism Research and Monitoring of Zhonghaicun Landslide in Southwest China. Remote Sens. 2021, 13, 1653. https://doi.org/10.3390/rs13091653

Academic Editor: Edward Park

Received: 17 March 2021

Accepted: 20 April 2021

Published: 23 April 2021

Publisher's Note: MDPI stays neutral with regard to jurisdictional claims in published maps and institutional affiliations.

Copyright: (c) 2021 by the authors. Licensee MDPI, Basel, Switzerland. This article is an open access article distributed under the terms and conditions of the Creative Commons Attribution (CC BY) license (https:// creativecommons.org/licenses/by/ $4.0 /)$.

\begin{abstract}
This paper presents a recent rainfall-induced landslide in China that occurred on August 21, 2020 and resulted in nine deaths. The sliding material traveled a distance of $800 \mathrm{~m}$, with an altitude difference of about $180 \mathrm{~m}$. A field investigation, remote sensing based on an unmanned aerial vehicle (UAV), in situ monitoring, and a rainfall data analysis were carried out to reveal the deposit characteristics, causative factors, post-landslide behavior, and the mechanism of the landslide. A saltatory micro-relief of the original slope determined the multiple-stage failure type of the slide, and also promoted the entrainment effect during the landslide movement. After the first-initiation sliding stage, the motion of this landslide involved typical progressive movement, and over time, the style of the runout generally turned into a flow-like form. Furthermore, the antecedent cumulative rainfall of $149.5 \mathrm{~mm}$ directly contributed to the occurrence of the landslide. Using the GB-SAR early warning system, the post-landslide residual failure was successfully predicted $10 \mathrm{~min}$ in advance. The combination of the UAV and GB-SAR technique can surely be beneficial for other inaccessible landslide investigations as well and improves the emergency rescue security.
\end{abstract}

Keywords: landslide; rainfall; entrainment; monitoring; mechanism

\section{Introduction}

Rainfall-induced landslides are one of the most disastrous hazards in mountainous regions, and can cause considerable casualties and great economic losses [1-4]. The initiation of this type of landslides can be attributed to the promoting effects of infiltrated rainwater in reducing slope stability by increasing the self-weight of rock and soil mass, producing a high pore-water pressure, and decreasing the material strength $[5,6]$. Recently, many catastrophic rainfall-induced landslides have occurred in mountainous areas. Examples include the Oso landslide in 2014 causing 43 fatalities, the most casualties in a landslide event in the history of the United States [7], the Sanxicun landslide in Dujiangyan, Sichuan, China in 2015 causing 166 deaths [8], and the Jichang landslide in Liupanshui, Guizhou, China in 2019 causing 52 casualties [9]. Particularly, in extreme rainfall events, landslides often occur in clusters that can be of dire consequences. Examples include the 29 June 2001 torrential rainfall (daily $240 \mathrm{~mm}$; maximum intensity $103 \mathrm{~mm} / \mathrm{h}$ ) that triggered 711 landslides in the Aso caldera region of Japan [10], more than 150 landslides occurred in the eastern part of the Czech Republic on 16-18 May 2010 (cumulative rainfall > $300 \mathrm{~mm}$ ) [11], and 1774 landslides were induced by the rainstorm on 2 September 2018 in Mengdong Town in the Yunnan Province, China [12]. It is, therefore, necessary to study the failure mechanisms of rainfall-induced landslides in-depth so as to prevent such a possible future catastrophe.

Conventional ground investigations are difficult to conduct on steep slopes in mountainous regions, many of which are unreachable. Remote sensing methods involving 
terrestrial-based technologies, light detection and ranging, infrared thermography, and ground-based radar interferometry are increasingly being considered as efficient techniques for characterization and monitoring of landslide areas in response to enhance the accuracy, efficiency, and convenience [13,14]. Unmanned aerial vehicles (UAVs) are adopted in particular because of their capability of obtaining multiple photographic perspectives of landslide area and allowing agile deployments capable of obtaining both high-spatial and temporal resolution data $[15,16]$. Geotags involving coordinates and orientation information are stored in the photographic records, which are fundamental for a geo-reference system of point clouds acquired from digital photogrammetry reconstruction algorithms. Currently, UAVs, equipped with high-pixel optical cameras, have been applied to study landslides [17]. Combined with data processing software, such as ContextCapture by Bentley Inc. [18] or Pix4Dcapture by Pix4D S.A. [19], allow recognizing, mapping, and analyzing landslides [20-22].

After landslides, real-time monitoring has always been a key to the on-site emergency rescue. Substantial techniques have been utilized, involving Global Navigation Satellite Systems and the in-place inclinometer (IPI) [23-25]. However, these traditional methods are usually time-consuming and are incapable of emergency rescue. New tools such as Ground-based SAR (GB-SAR) can be used to monitor landslide motion and reduce landslide risk by providing early warnings [26,27]. Many previous studies have focused on the deformation trends and mechanisms of landslides [28,29]. However, the responses of the emergency rescue based on GB-InSAR based monitoring has always been the key to the in-depth study of such landslides. The combination of on-site investigations and the GBSAR monitoring technique can shed light on the basic features and evidence the presence of "unstable" blocks on the ground of large landslides in high alpine environments [25,26]. The GB-SAR is a terrestrial remote sensing imaging system based on radar, which has developed to an extent where it can present powerful management of geological disasters. It is known for its high geometric accuracy, high sampling frequency and strong adaptability to mountainous area. The post-landslide emergency response, in particular, for ensuring the safety of a rescue team and avoiding a second disaster, requires high geometric accuracy of the residual deformation. In recent years, the GB-SAR technique has attracted increasing interests in post-landslide monitoring [30,31], which can provide deformation maps of individual slopes at shorter intervals (up to the minute level), overcoming the limitations of poor mobility in satellite data acquisition [32,33]. In addition to the high-frequency sampling speeds, GB-SAR can also provide high-resolution images and wide monitoring areas (up to several thousand meters) [34]. Using GB-SAR, the persistent deformation measurements are available in a limited area. As a new type of active microwave remote sensing technology, it can obtain micro-deformation (sub-millimeter level) to monitor the landslide area. The implementation of the instrument is simple as well. As there is no need to enter the landslide area, it can be used for emergency management easily.

This paper presents a case study illustrating the use of a UAV to investigate a recent rainfall-induced landslide and GB-SAR to monitor the post-landslide deformation. The study site is located on the bank slope of the Provincial road S435, about $4 \mathrm{~km}$ northwest of the Hanyuan County, China. The analysis presented in this paper corresponds to the event that occurred at 03:50 a.m. on 21 August 2020. The post-landslide digital elevation model (DEM) was established based on the point cloud collected by a UAV. The volume of the source material and the scale of the landslide deposit can be calculated from the difference between the DEM before and after the landslide, which can be used to analyze the accumulation characteristics of the landslide. The dynamic parameters of the landslides and the interactive process between avalanche and substrate cannot be acquired in the field. As one method of addressing this, the micro-deformation sensing L-band SAR provides new insights in reproducing these dynamic processes. GB-SAR was implemented to monitor the behavior of the post-landslide slope, allowing safety and efficiency of emergency rescue and mitigation. This proposed approach provides an easy-conducted and efficient workflow for back-analyzing and monitoring of a landslide. 
The results of this paper could serve as a foundation for future research on rainfall-induced landslides, which gives new insights into landslide prevention and mitigation.

\section{Study Area}

The landslide occurred in the East Hanyuan County ( $\left.102^{\circ} 41^{\prime} 51.17^{\prime \prime} \mathrm{E}, 29^{\circ} 20^{\prime} 34.73^{\prime \prime}\right)$, Ya'an City, Sichuan Province, on the left bank of the Dadu River (Figure 1). The landscape in this region is dominated by strong incising of middle and high mountains, which are generally higher in the north and east and lower in the southwest. The elevation is $1200 \mathrm{~m}$ at the hilltop of the slope and $910 \mathrm{~m}$ at the toe, resulting in a topographic elevation difference of $290 \mathrm{~m}$. The climate in the study area is subtropical monsoon, with an average annual precipitation of $745.1 \mathrm{~mm}$. Rainfall is usually concentrated in July to September, which accounts for about $80 \%$ of the annual rainfall, frequently in the form of continuous rainfall. The annual average temperature is approximately $26.2^{\circ} \mathrm{C}$. The exposed strata in the study area consist of the (i) Quaternary sediments; (ii) the Upper Triassic Xujiahe Formation $\left(\mathrm{T}_{3} \mathrm{x}\right)$ which are composed of thinly layered purplish-red mudstone intercalated with light yellow sandstone.

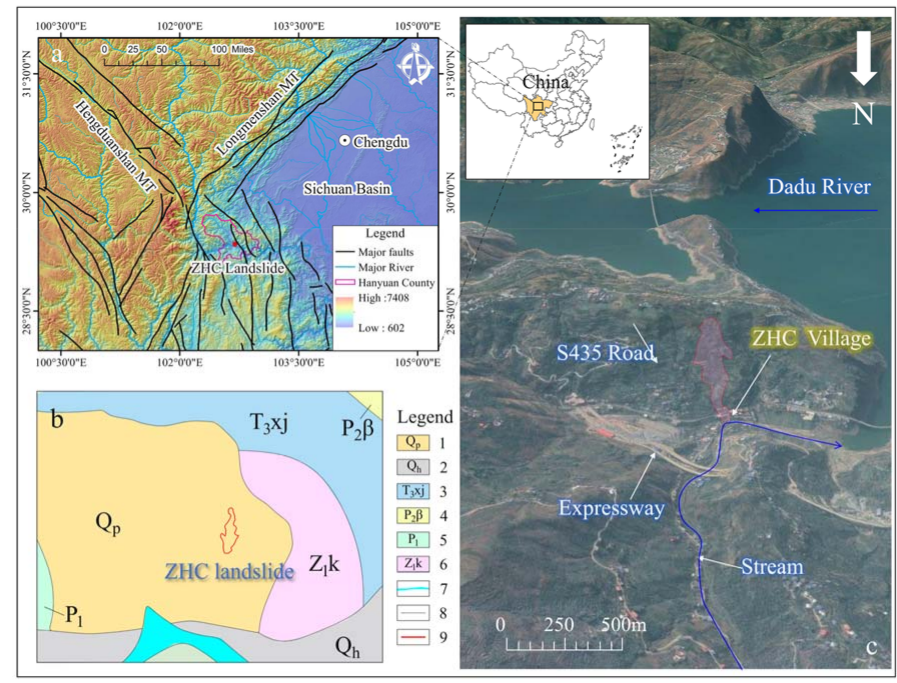

Figure 1. (a) Regional tectonic map. (b) Stratigraphic lithologic map: 1. Quaternary Pleistocene diluvium; 2. Quaternary Holocene diluvium; 3. Upper Triassic Xujiahe Formation which are composed of thinly layered purplish-red mudstone intercalated with light yellow sandstone; 4 . Upper Permian Emeishan basalt; 5. Lower Permian limestone; 6 . Dark purple feldspar-lithic sandstone of the lower Sinian Kaijianqiao Formation; 7. Dadu River; 8. Geological boundaries; 9. Boundary of ZHC landslide). (c) Geomorphology map of the ZHC landslide.

\section{Characteristics of Landslide}

Field investigations combined with unmanned aerial vehicle (UAV) surveys were conducted to characterize the ZHC landslide. Specifically, the DJI Phantom 4 Pro UAV was adopted to obtain high-resolution images and a digital surface model (DSM). A fixed flight altitude of $210 \mathrm{~m}$ was planned based on the terrain of the landslide area. A total of 666 images were acquired covering the landslide area with both vertical and oblique views. Images were processed using the ContextCapture software, resulting in a point cloud dataset of 24 million points. The UAV survey results suggested that the ZHC landslide originated at the hill peak of slope at about $1130 \mathrm{~m}$ in elevation; the landslide ran downslope and came to rest at the stream bottom at $910 \mathrm{~m}$ a.s.l. with a vertical drop of $220 \mathrm{~m}$ over a distance of $620 \mathrm{~m}$. Based on the landform expression and geological material, the landslide area could be divided into three zones: source zone, overloading and entrainment zone, and accumulation zone (Figures 2 and 3 ). 


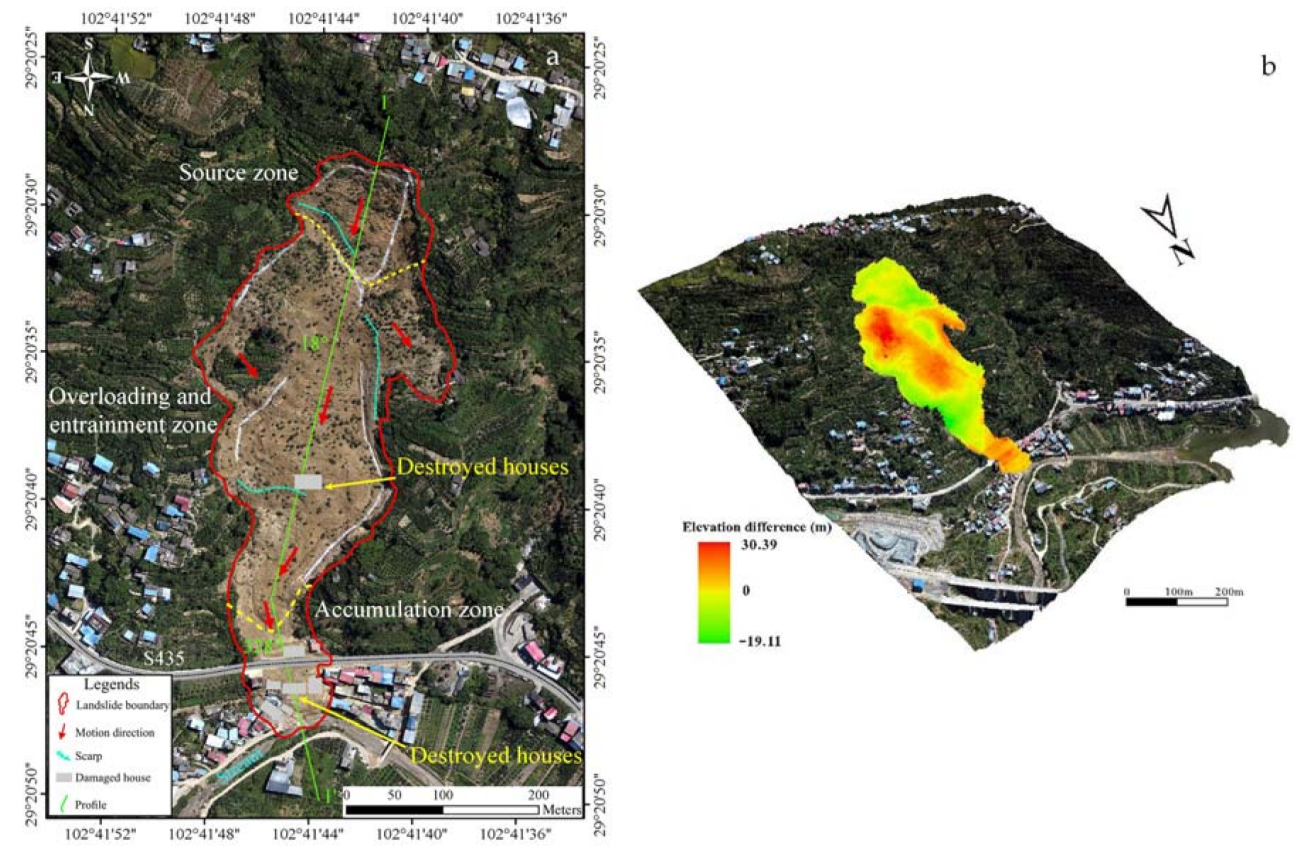

Figure 2. (a) Orthophotos showing the landslide boundary, source zone, overloading and entrainment zone, and accumulation zone. Orthophotos are made from UAV images using the ContextCapture software with a 0.08-m resolution. (b) Pre- and post-landslide elevation difference.

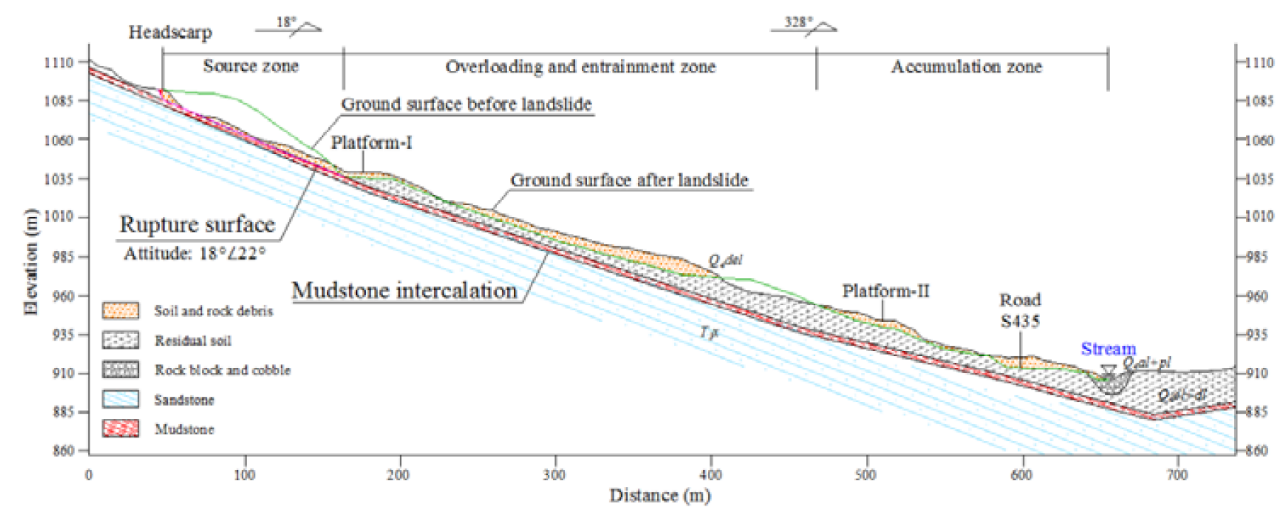

Figure 3. Cross-section of the ZHC landslide (1-1' in Figure 2a).

\subsection{Source Zone}

The source zone of the landslide is located at an elevation of $1075 \mathrm{~m}$ to $1130 \mathrm{~m}$ with a relative height difference of $55 \mathrm{~m}$. The pre-event slope is steep with an average inclination angle of $40^{\circ}$. The width of the main scarp was $80 \mathrm{~m}$ and the length along the main motion direction was approximately $125 \mathrm{~m}$. This zone has an area of $1.25 \times 10^{4} \mathrm{~m}^{2}$ and an average thickness of $15 \mathrm{~m}$, thus the estimated volume is $19.00 \times 10^{4} \mathrm{~m}^{3}$ (Figure 4). The source materials are mainly composed of eluvium and highly weathered sandstone incorporated with mudstone. Tension cracks were observed at the headscarp after the landslide and they controlled the unstable block at the rear edge of the source zone (Figure 5). 


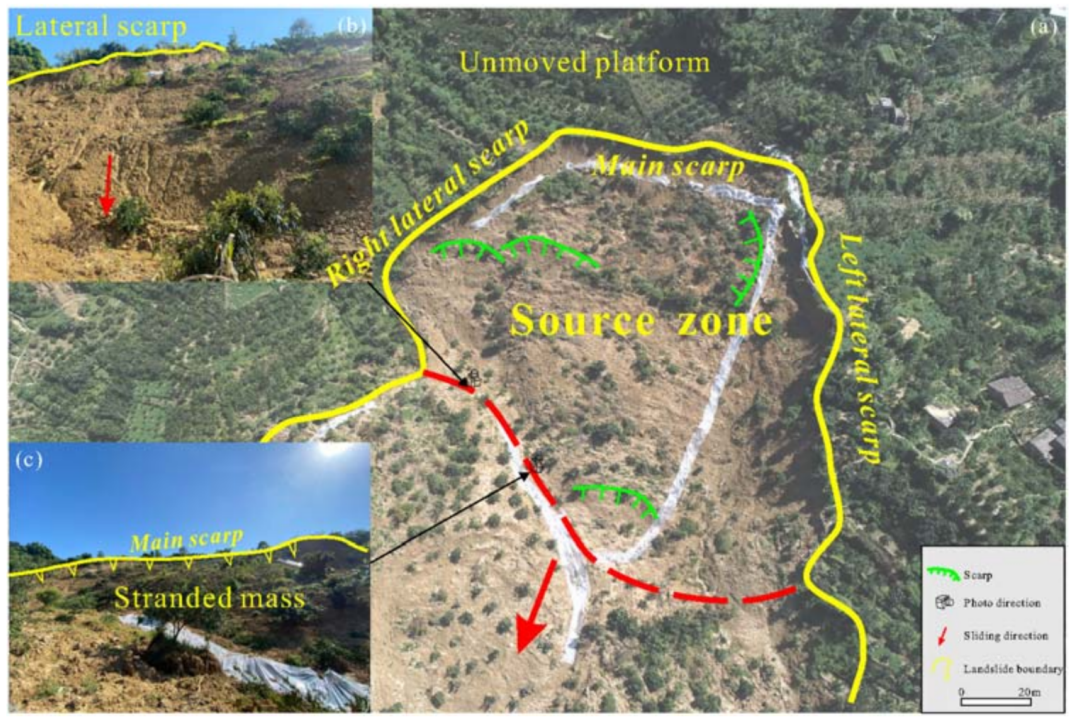

Figure 4. (a) Overall view of the source zone. After the landslide occurred, the main scarp formed at the rear edge, and the main slide direction of the landslide was $18^{\circ}$ in the source zone. (b) Right lateral scarp. (c) Stranded sliding mass below the main scarp.

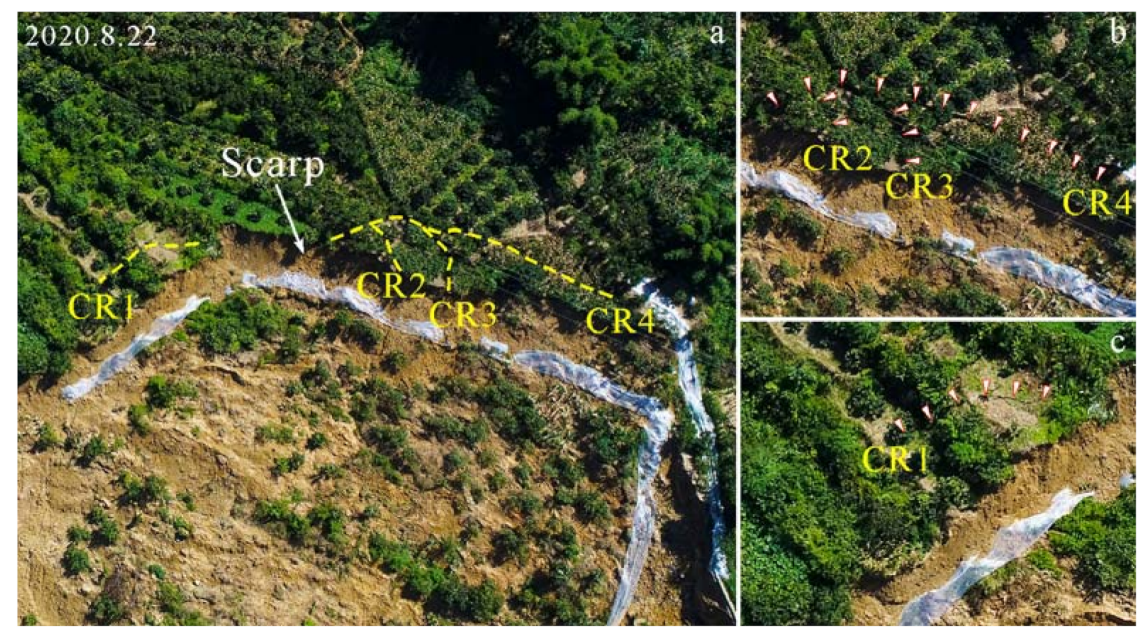

Figure 5. (a-c) The tension cracks observed at the headscarp after the landslide. "CR" is crack.

\subsection{Overloading and Entrainment Zone}

The overloading and entrainment zone is located in the downslope direction of the source zone and terminates at the toe of the slope of road S435, with an elevation of $965 \mathrm{~m}$ to $1075 \mathrm{~m}$. Based on the remote sensing image interpretation before the landslide and site surveys, the morphological characteristics of the original slope were two gentle platforms (Figure 6). After the initiation of the landslide in the source zone, it rapidly transformed into a debris flow, and then it dynamically impacted and loaded the first-level platform (platform-1) along its path, leading to a significant increase of the volume. Similarly, when the displaced materials reached the second-level platform (platform-2), the overloading and entrainment effect occurred again, forming an obvious sliding area. Because of this effect, trees in the motion path near the right boundary fell on the outside of the area, which indicated that the sliding body had the displacement component towards the right front side (Figure $7 \mathrm{~b}$ ). In addition, an about $15 \mathrm{~m}$ height scarp was formed in the left lateral boundary (Figure 7a), while no obvious scarp but overlap phenomena can be observed in the right boundary in this zone (Figure 7c). Therefore, the moving path shifted to the right side (NNE) was identified. 


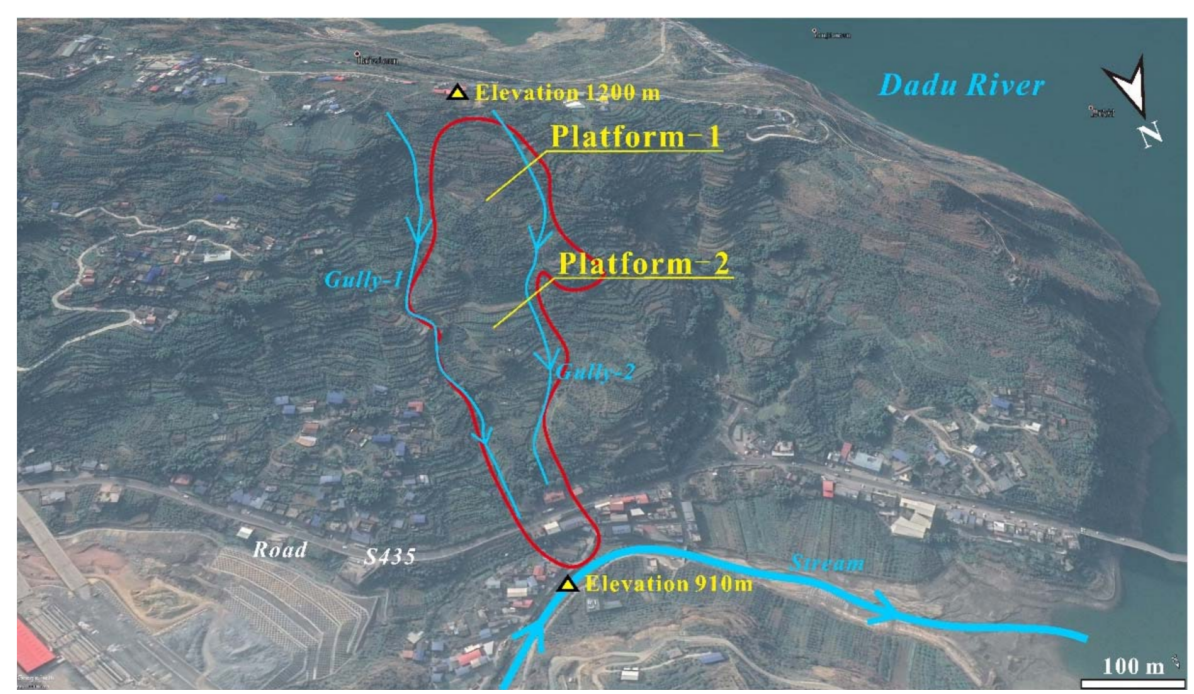

Figure 6. Topographic features of the area before the landslide. There are two platforms and two gullies in the landslide area.

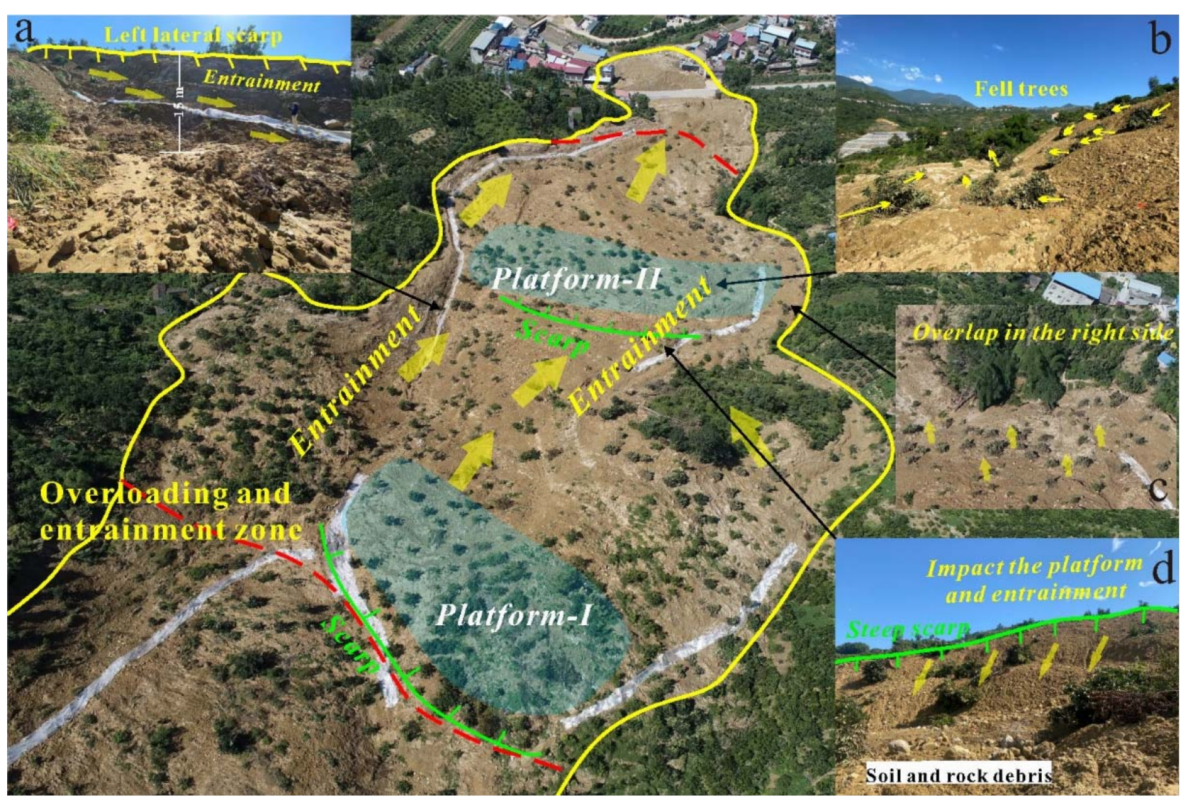

Figure 7. Overall photo and features of the entrainment area. (a) Lateral scarp at the left boundary. (b) The trees on the slope were pushed sideways. (c) Overlap phenomena in the right side. (d) Steep scarp formed after landslide in the middle part.

This zone has a length along the motion direction of about $400 \mathrm{~m}$, an average width of about $165 \mathrm{~m}$, a maximum thickness of $20 \mathrm{~m}$, an average thickness of $15 \mathrm{~m}$, and a volume of about $100 \times 10^{4} \mathrm{~m}^{3}$. The deposit materials consisted of moderately wet, yellow soil and fragmental sandstone interlayered with mudstone. Two gentle platforms formed after the movement came to rest. Thereinto, the average elevation of the platform-I is approximately $1040 \mathrm{~m}$, with a length of about $32 \mathrm{~m}$, a width of about $120 \mathrm{~m}$, and a gradient of $4^{\circ}$ (Figure 7). The back wall of the landslide is located above this platform. The platformII is located in the middle of the landslide area, with an average elevation of approximately $940 \mathrm{~m}$, with a length of about $15 \mathrm{~m}$, a width of about $150 \mathrm{~m}$ (Figure 7). Two high-steep scarps are observed on the front edge of these platforms (Figure 7), and the heights are $15 \mathrm{~m}$ and $16 \mathrm{~m}$, the slope are about $32^{\circ}$ and $35^{\circ}$, respectively. In the lower part of this zone, due to the complete saturation of soils, the fluidization phenomenon was observed (Figure 8), which indicated that a flow-like movement occurred. 


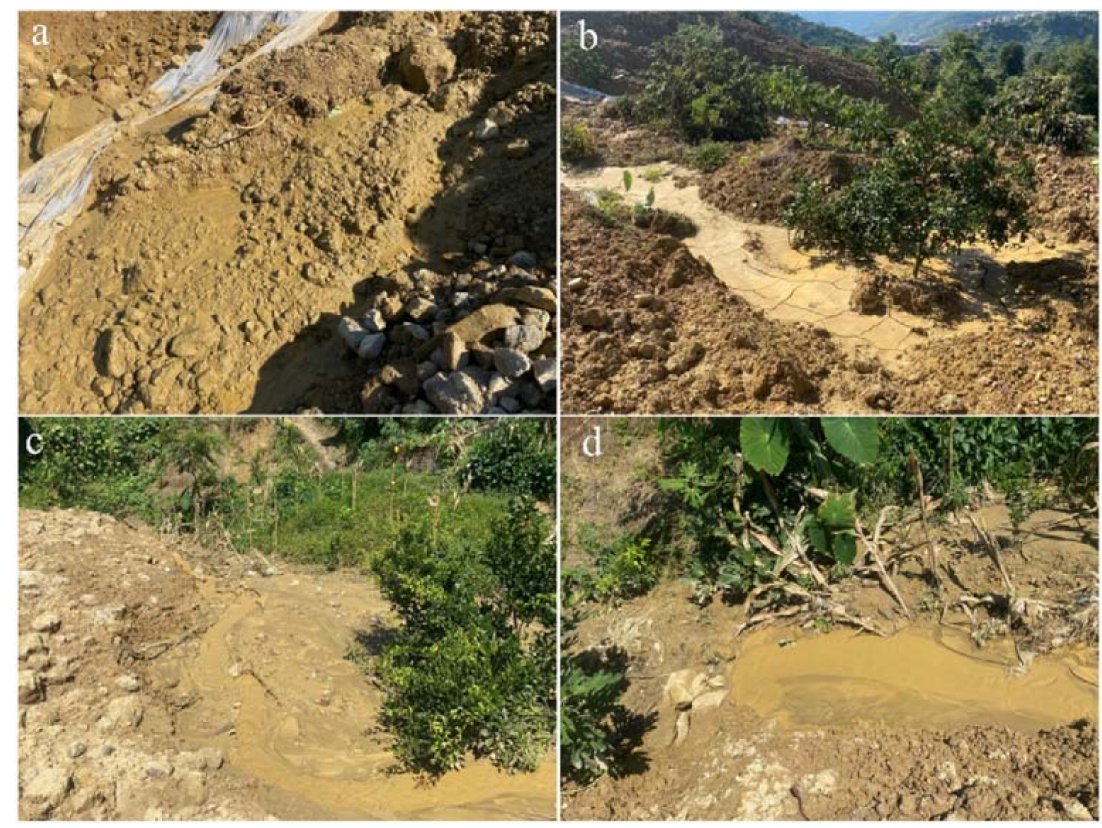

Figure 8. Fluidization phenomenon in the $(\mathbf{a})$ rear, $(\mathbf{b}, \mathbf{c})$ middle and $(\mathbf{d})$ front of landslide area.

\subsection{Accumulation Zone}

The downward movement of the sliding mass was stopped by the gentle terrain and houses at the bottom of the slope. The accumulation zone has a length of $95 \mathrm{~m}$, a width of $80 \mathrm{~m}$, an average thickness of $10 \mathrm{~m}$, and a volume of about $7.6 \times 10^{4} \mathrm{~m}^{3}$. There are eight buildings (involving a health-center) at the toe of slope buried, the road S435 was blocked, and a stream at the bottom of the valley was locally dammed (Figure 9). Figure 9b shows a house at the left boundary of the landslide that was severely damaged by the sliding mass. Field observations indicated that the deposits were mainly a mixture of soils and rock gravels (Figure 10). In general, the rock gravels were fine-grained and had a particle size of about $8-10 \mathrm{~cm}$.

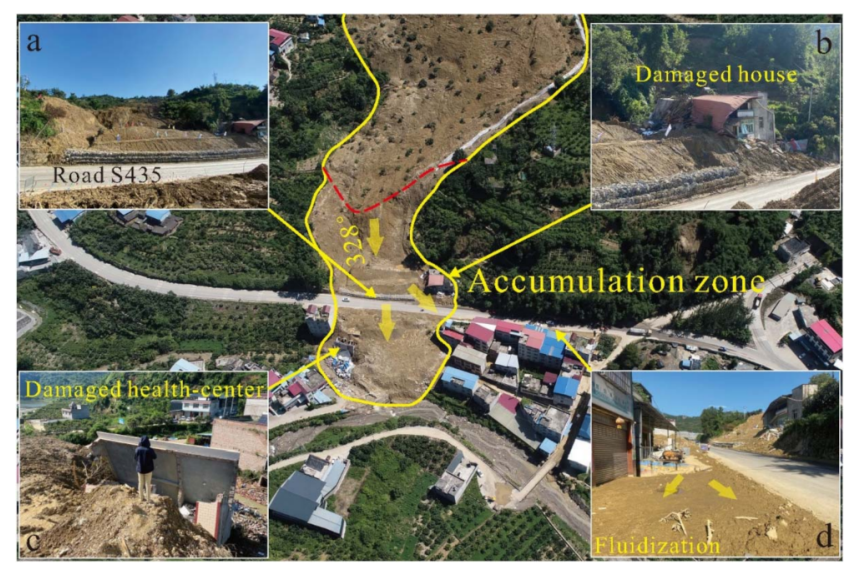

Figure 9. Photographs showing landslide impacts in the accumulation zone. (a) Reinforced gabion conducted for the road restoration. $(\mathbf{b}, \mathbf{c})$ Damaged houses and health-center. (d) Fluidization phenomena. 


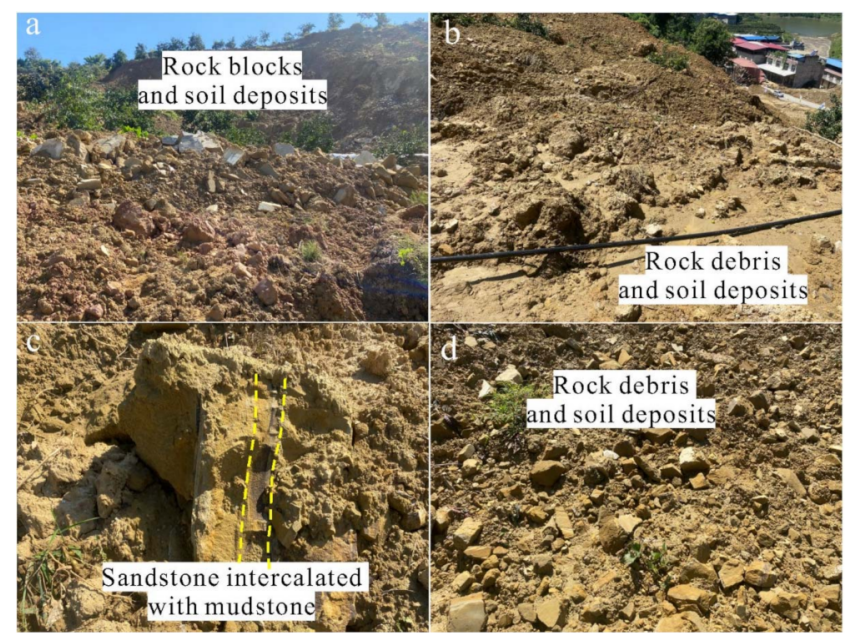

Figure 10. Accumulation features comprising soil with high gravel content. $(\mathbf{a}, \mathbf{b}, \mathbf{d})$ The rock debris in the front, middle and rear respectively. (c) Sandstone intercalated with mudstone.

\section{Monitoring Using GB-SAR}

Because of the occurrence of the landslide, the dynamic action and the unloading effect led to the formation of fresh cracks and promoted future deformations. Immediately after the landslide, specifically, at around 17:45 p.m. on 21 August, the study area was monitored by using the Micro-deformation sensing radar L-band synthetic aperture radar (MDSRLSAR), a type of GB-SAR, to avoid possible subsequent landslide and ensure the safety of the emergency rescue (Figure 11) (http:/ / www.elecfans.com/d/1285955.html, accessed on 16 March 2021).

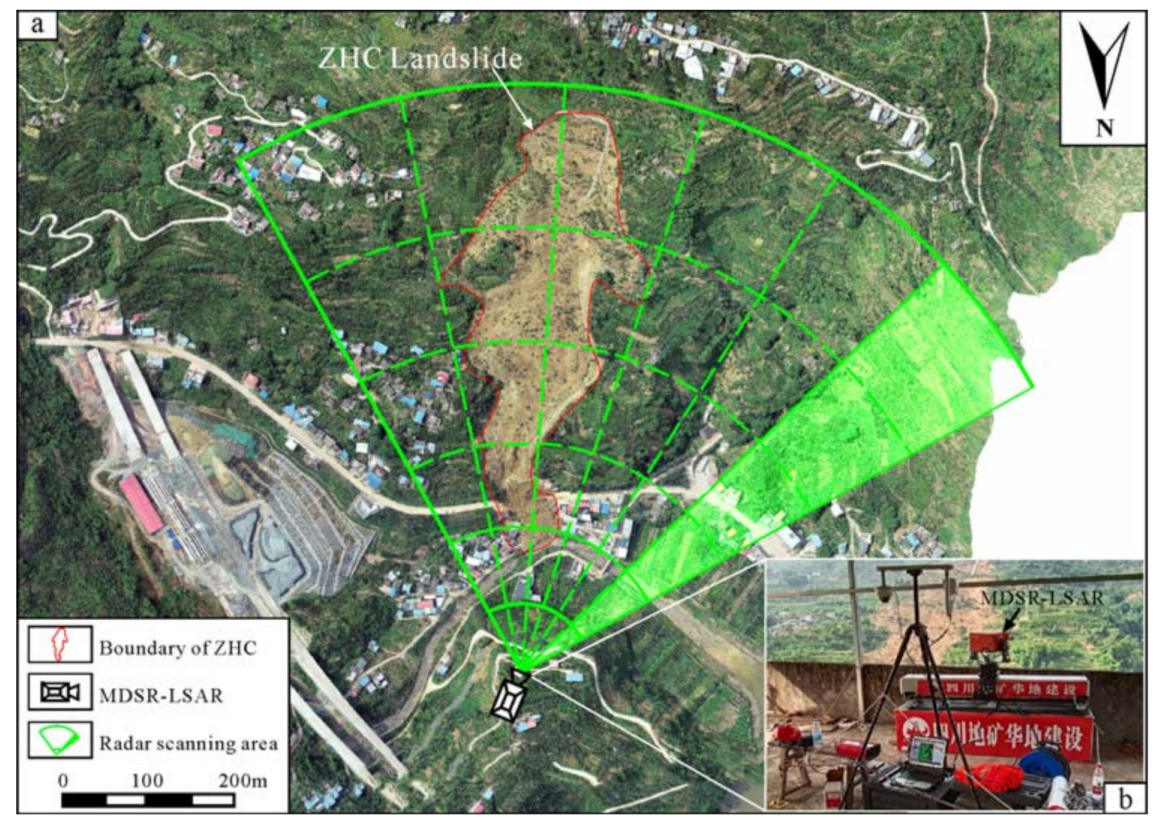

Figure 11. (a) Region of the in-site monitoring after the ZHC landslide. (b). The MDSR-LSAR instrument used for this monitoring.

Monitoring began at 17:45 on 21 August 2020, and the entire cumulative displacetime data within the landslide area and surrounding region in real-time were successfully recorded. The sampling frequency is about $30 \mathrm{~s}$. The cumulative displacement reached $197.35 \mathrm{~mm}$ at 13:19 p.m. on 22 August 2020, the deformation rate exceeded the alarm value $35 \mathrm{~mm} / \mathrm{h}$ and the rate increment exceeded the alarm value $10 \mathrm{~mm} / \mathrm{h}$ [23,31,35] (Figures 12 and 13). At the same time, the automatic message was released by the system. 
After receiving the warning information, the involved departments immediately organized an emergency response and evacuated the rescue site. About 10 min later, a second collapse occurred at the landslide site, and the cleared road area was buried again. Fortunately, due to the successful early warning, this collapse did not cause casualties and property damage (Figure 12).

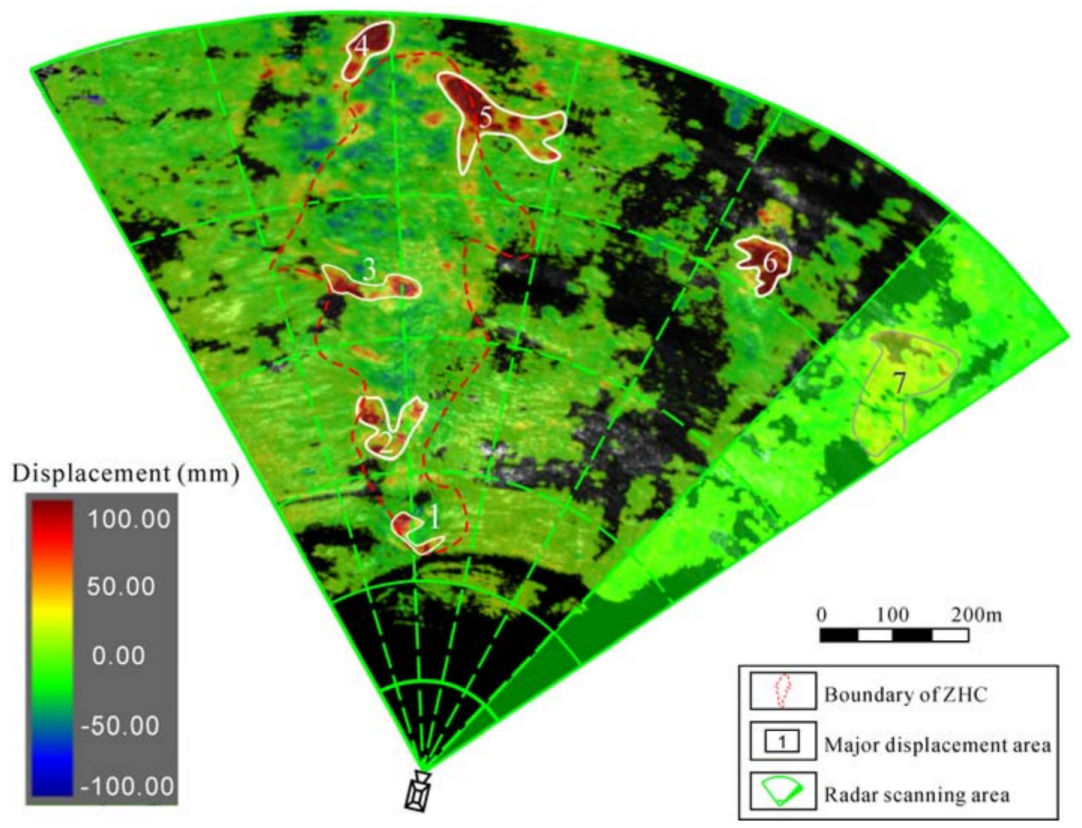

Figure 12. Cumulative deformation map produced by the MDSR-LSAR from 17:45, 21 August to 13:19, 22 August.

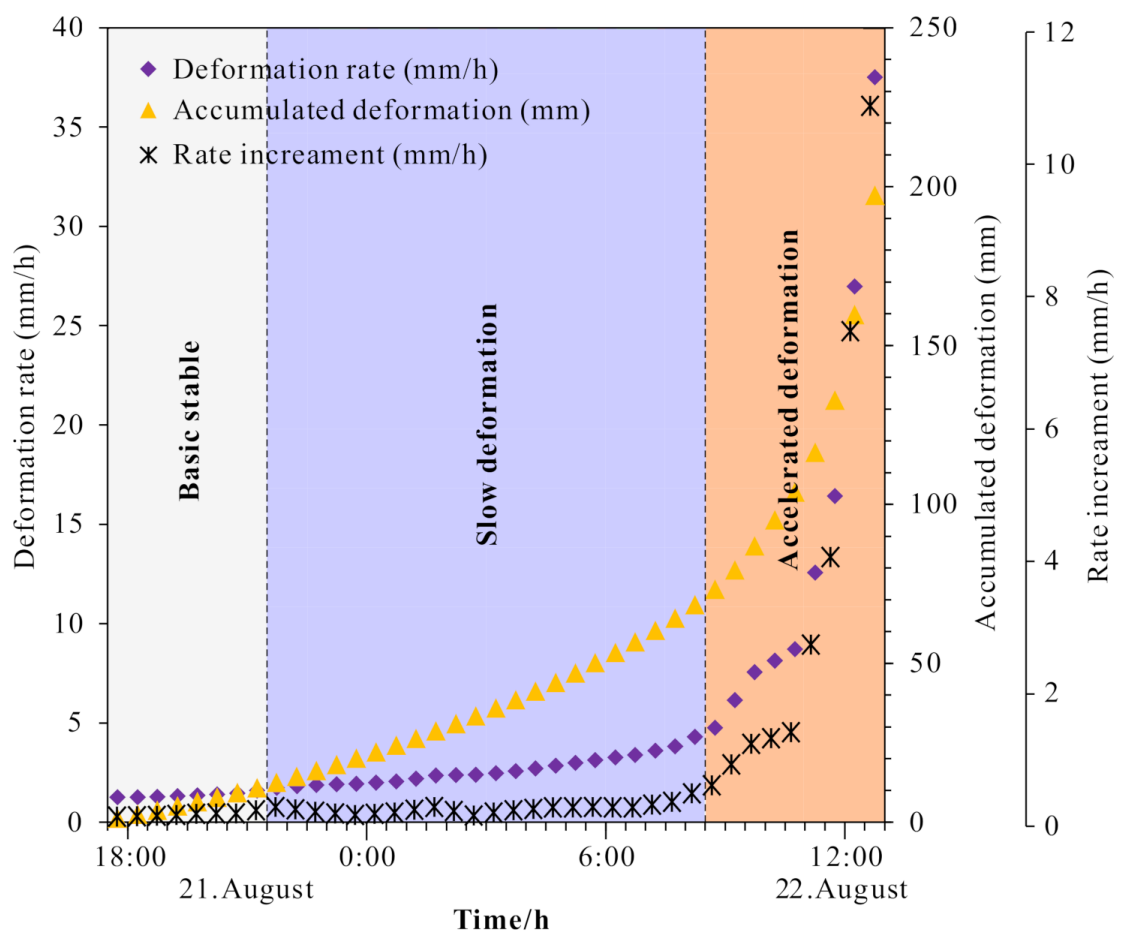

Figure 13. The detailed process of early warning in the ZHC landslide by displacement monitoring at area 1 by the MDSR-LSAR from 17:45, 21 August to 13:19, 22 August.

Monitoring data showed that within the range of the landslide, the deformation was mainly located in the rear of the source area. It is suggested that the deformation 
was mainly induced by the traction action near the trailing edge of the main scarp, with a deformation rate of about $0.2-0.3 \mathrm{~mm} / \mathrm{h}$. In addition, the middle and lower accumulation zones have no significant deformations, thus indicating that the entire landslide area was in a stable state.

\section{Causative Factors}

\subsection{Topography}

The landslide area is located in the Hanyuan County of Western Sichuan Province, and is situated in the catchment zone of the Dadu River. Within the region, the mountains are highly eroded and deep V-shaped valleys are well developed. In addition, the positive and negative landforms are relatively developed. The effects of topography on mechanisms of the landslide are significant. In the landslide area, high and steep topography conditions are present, with the highest elevation of $1200 \mathrm{~m}$, and the lowest elevation of $910 \mathrm{~m}$. The slope had two steep scarps preceding the landslide, presenting a "stepped" shape (Figure 7), which allow the multiple sliding during the landslide runout. The ZHC landslide is located on the right bank of the road S435, due to the road construction, a steep topography formed on the right bank, with a height difference of about $15 \mathrm{~m}$, and a slope of about $35^{\circ}$, providing a favorable condition for slope deformation (scarp 1). The second scarp is located in the middle section of the slope, which has a steep slope of about $40^{\circ}$, and a height difference of $20 \mathrm{~m}$ (scarp 2). On the one hand, the existence of gentle platforms above these scarps limited the movement of the sliding mass and decreased the kinetic energy. On the other hand, the terrain condition promoted the overloading-impact-induced erosion, which had a significant contribution to the entrainment during the sliding process, and provided conditions for its volume enlargement.

\subsection{Geological Material}

The strata in the landslide area mainly consisted of highly weathered sandstone interlayered with mudstone and soil materials, with a loose structure, high permeability, and a condition of rapid infiltration of precipitation and surface water. The soil layer is silty clay with gravels, the content of coarse-grained gravel is less than $25 \%$, the content of fine particles is high. Therefore, under the heavy downpour circumstance, the rock and soils are considered to have been saturated by the infiltration of rainwater, and thus the slope had become highly vulnerable to recurrent slope failures. Figure 10 shows the displaced rock blocks, with a highly weathered surface and poor mechanical properties. The high content of soils within the sliding mass conditioned the fluidization phenomenon, supporting the flow-like movement during the moving process.

\subsection{Rainfall}

The catastrophic landslide occurred in the rainy season. Hanyuan County had experienced continuous heavy rainfall for a month. The rainfall data gathered from a local meteorology station for the week preceding the landslide disaster is shown in Figure 5. It indicates that there are two-round intense heavy rainfalls over the past seven days (59.1 mm, $42 \mathrm{~mm}$ on 16 August and 18 August, respectively). The cumulative rainfall in the last seven days before the event was $149.5 \mathrm{~mm}$ and the most intense hourly rainfall reached $26.5 \mathrm{~mm}$ (Figure 14). The continuous torrential rainfall resulted in the saturation of soils, reduced the resistant shearing force of the slope, which was determined as the direct trigger of this landslide. 


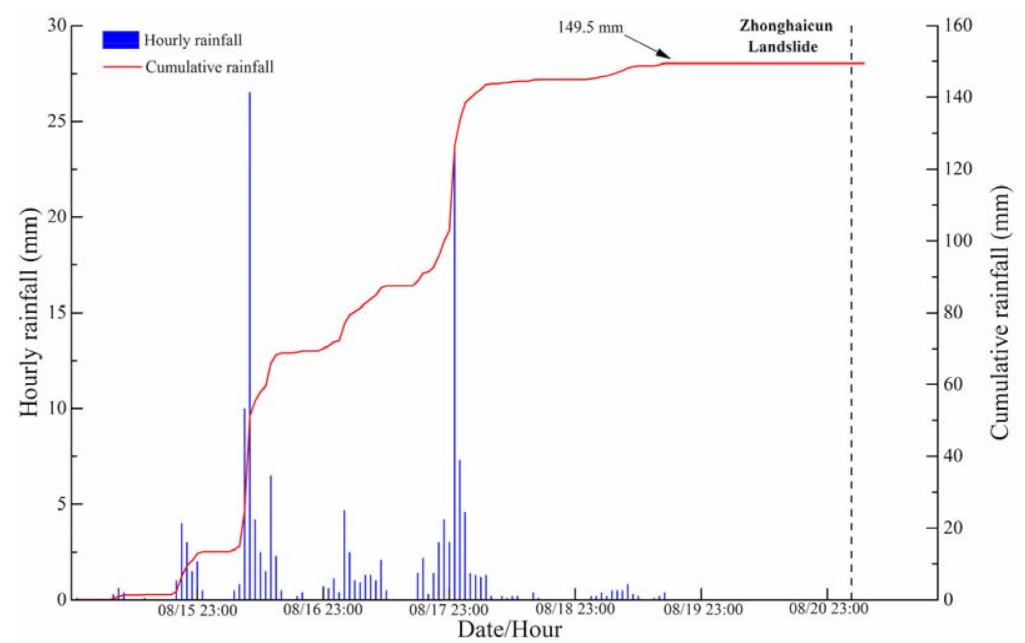

Figure 14. Precipitation in the ZHC landslide area. One week prior to the landslide, there were two heavy rainfall events on 16 August 2020 and 18 August 2020 with a cumulative $149.5 \mathrm{~mm}$ of rainfall.

\section{Failure Mechanism}

Based on the forementioned analysis, the failure of the ZHC landslide mainly experienced two stages: initiation stage and entrainment stage, which are described as follows.

\subsection{Initiation Stage}

Before the landslide, rainwater permeated into the interior of the slope, forming a higher hydrostatic head at the rear. On-site investigations revealed that there are groundwater outlet points in the gullies surrounding the source zone, so that the groundwater inside the slope can be discharged in time. The hydrostatic pressure inside the slope reaches a dynamic balance, so that the slope remains stable. Because of the long period of the intense rainfall in August, 2020, the groundwater level increased significantly, and the pore water pressure buildup has destabilized the upper slope (Figure 15a). About $19 \times 10^{4} \mathrm{~m}^{3}$ of material initiated from this zone and reached the gentle section in the middle.

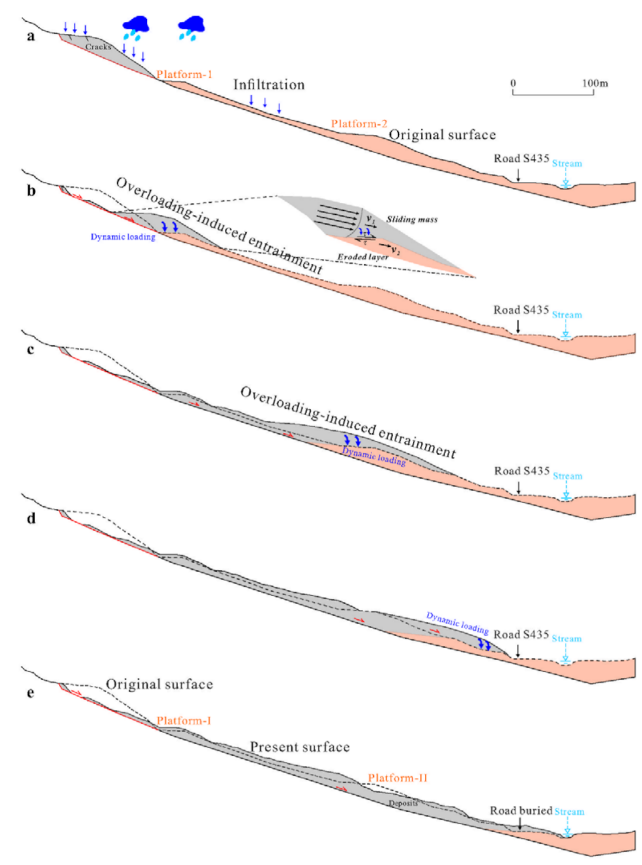

Figure 15. Mechanism of the ZHC landslide. (a). Initiation sliding occurred due to the heavy rainfall. (b). First entrainment sliding. (c). Second entrainment sliding and flow-like moving. (d). Third entrainment sliding. (e). Topography features after landslide. 


\subsection{Entrainment and Moving Stage}

The displaced rock and soil mass impact the gentle slope platform at the toe of the source zone (located near 1040m) under the action of the huge potential energy, causing the detritus to extend to both sides within $100 \mathrm{~m}$ of the lower part of the area (Figures 4 and 15b). The vegetation fell diagonally to both sides under the impact of airwaves (Figure $7 \mathrm{~b}$ ). Due to the buffer of the gentle slope platform, the rear sliding mass slowed down due to the loss of kinetic energy. After sliding down the slope for a certain distance, it settled on the gentle slope in the middle and upper parts of the slope, leaving about $9 \times 10^{4} \mathrm{~m}^{3}$ of loose accumulation near the source zone. Induced by a dramatic overloading and entrainment effect by the initiative landslide, the central slope slid downward progressively (Figure 15b,c). Moreover, the sliding force was higher and the material volume became larger, instantly swallowing the houses on the hillside. Finally, when the sliding mass reached the toe of the slope, the cutting slope began to slide, that was, the third slide occurred (Figure 15d,e).

\section{Discussion}

When sliding masses involving large energy travel over complex terrain composed of substrate, such as colluvium and eluvium, these moving masses unavoidably impact the substrate on the motion path and result in scour and entrainment. This scour and entrainment processes often increase the volume of deposit. High-position landslides containing entrainment are ubiquitous. Hungr and Evans [36] proposed the Entrainment Ratio (ER) to quantify the effect: (ER $=\mathrm{VE} \div \mathrm{VR}(1+\mathrm{FF})$, while VE is the volume of the entrained substrates, VR is the volume of the initial volume, and FF is the volume of fragmentation-induced expansion (usually defined as 0.25 ). In practical cases, the volume of the Flims landslide increased from $10 \times 10^{4} \mathrm{~m}^{3}$ to $40 \times 10^{4} \mathrm{~m}^{3}$, with an ER value of 2.2 [36]. The Xinmo landslide has an initial volume of $3.9 \times 10^{6} \mathrm{~m}^{3}$ and a deposition volume of $16 \times 10^{6} \mathrm{~m}^{3}$, with an ER value of 2.2 [8]. The Baige landslide volume enlarged from $1.6 \times 10^{6} \mathrm{~m}^{3}$ to $8.6 \times 10^{6} \mathrm{~m}^{3}$, with an ER value of 3.3 [37]. In the ZHC landslide, the ER value is calculated as 3.7, with the values of VE and VR of $88.6 \times 10^{4} \mathrm{~m}^{3}, 19 \times 10^{4} \mathrm{~m}^{3}$, respectively. During the entrainment process of highposition landslides, the interaction objects are the initial sliding mass and the immovable rock and soil masses on the moving path. The physical and mechanical properties and the action mode of the entrained masses have a crucial influence on the entrainment characteristics. Figure 16 shows four typical entrainment modes due to the impacting force: (i) intact impact and scraping, (ii) fragmented impact and plough, (iii) flow-like entrainment, and (iv) overloading and entrainment [38,39].
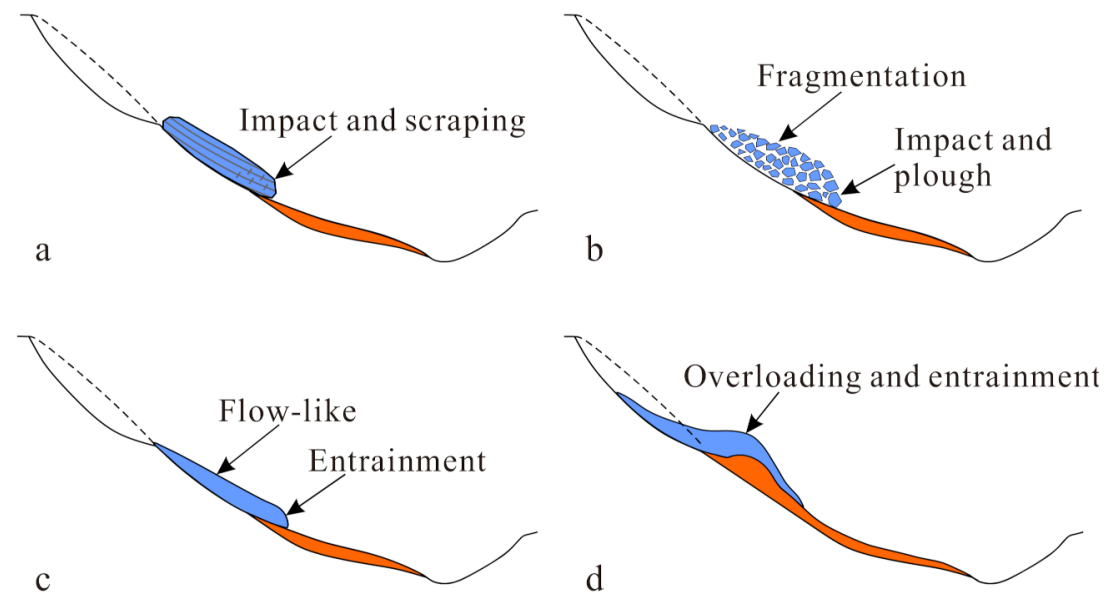

Figure 16. The typical entrainment modes. (a). Intact impact and scraping. (b). Fragmented impact and plough. (c). Flow-like entrainment. (d) Overloading and entrainment. 
In the ZHC landslide, after the materials slid from the source area, due to the topographic and material constraints, it loaded successively and accumulated on the middle and lower slopes in the overloading and entrainment zone, thus led to sequent failure continuously [40,41]. This entrainment mode is mainly caused by the energy of the upper landslide, which is similar to the second Baige landslide [37]. It is concluded that the topography and substrate material have a significant contribution to the erosion and entrainment process of high-position landslides. Especially, the substrate with lower shear strength allows for easier and larger-volume entrainment [42].

\section{Conclusions}

This paper presents a detailed investigation and mechanism study of the catastrophic rainfall-induced landslide that can be expected at the given study-site in the Hanyuan County of China, namely the ZHC landslide, which is a representative case of a geological disaster adjacent to a settlement area in high alpine environments. This landslide occurred at 03:50 a.m. on 21 August 2020, causing nine deaths. Based on UAV digital photogrammetry and GB-SAR monitoring, the characteristics, causative factors, and failure mechanism were revealed, and the safety of the emergency rescue was guaranteed. The following conclusions were formed:

1. The occurrence of the ZHC landslide is attributed to the joint effect of topographic, material and rainfall factors. The step-like terrain of the slope determined the failure mode as a multiple slide, and the scarps below platforms provided well free surfaces. Unconsolidated soil materials and highly weathered sandstone intercalated with mudstone laid a foundation for rainwater infiltration and groundwater seepage. The continuous torrential rainfall preceding the landslide resulted in the saturation of soils, reduced the resistant shearing force of the slope, which was determined as the triggering factor of this landslide.

2. The process of the landslide can be divided into two stages: initiation stage and entrainment and moving stage. About $10 \times 10^{4} \mathrm{~m}^{3}$ of material initiated from the source zone and then the displaced sliding masses formed an overloading and entrainment effect on the residual rock and soil mass in the central section of the slope. Due to the step-like terrain constraint, two entrainments occurred on both platforms in the overloading and entrainment zone.

3. The GB-SAR implemented immediately after the landslide monitored the slope stability and development trends. A second collapse occurred at 13:29 p.m. on 22 August, buried the road again. Fortunately, due to the early warning of the GB-SAR at 13:19 p.m., prompt action taken by local workers averted human and severe economic losses. It could be selected as a good reference for real-time monitoring methods and early warning systems for post-landslide emergency rescue. The combination of the UAV and the GB-SAR technique can surely be beneficial for other inaccessible landslide investigations as well and improves the emergency rescue security.

Author Contributions: Conceptualization, B.L. and K.H.; methodology, M.H.; software, G.M.; validation, B.L. and M.W.; formal analysis, K.H.; investigation, B.L. and K.H.; resources, X.H.; data curation, M.H.; writing—original draft preparation, B.L. and K.H.; writing—review and editing, B.L. and K.H.; supervision, X.H.; project administration, X.H. and M.H.; funding acquisition, X.H. and M.H. All authors have read and agreed to the published version of the manuscript.

Funding: We gratefully acknowledge the financial support of the National Key Research and Development Program of China (2018YFC1505401), the National Natural Science Foundation of China (41731285), Youth Fund Project of NSFC (Grants No. 41907225) and Open fund of State Key Laboratory of geological disaster prevention and geological environment protection (Grants No. SKLGP2018K011) for their strong support for this topic.

Institutional Review Board Statement: Not applicable.

Informed Consent Statement: Not applicable. 


\section{Data Availability Statement: Not applicable.}

Acknowledgments: We are grateful to Engineers Qiuyu Pang from Becton, Dickinson Company and Engineer Meng Li from Southwest Petroleum University for their help in the field investigations. We are also grateful to the reviewers of this manuscript for their good suggestions and useful comments.

Conflicts of Interest: The authors declare that they have no known conflict of interests or personal relationships that could have influenced the work reported in this paper.

\section{References}

1. Stark, T.D.; Baghdady, A.K.; Hungr, O.; Aaron, J. Case study: Oso, washington, landslide of march 22, 2014-material properties and failure mechanism. J. Geotech. Geoenviron. Eng. 2017, 143, 05017001. [CrossRef]

2. Ma, G.; Hu, X.; Yin, Y.; Luo, G.; Pan, Y. Failure mechanisms and development of catastrophic rockslides triggered by precipitation and open-pit mining in Emei, Sichuan, China. Landslides 2018, 15, 1401-1414. [CrossRef]

3. Ouyang, C.; Zhao, W.; Xu, Q.; Peng, D.; Li, W.; Wang, D.; Hou, S. Failure mechanisms and characteristics of the 2016 catastrophic rockslide at Su village, Lishui, China. Landslides 2018, 15, 1391-1400. [CrossRef]

4. He, K.; Li, Y.; Ma, G.; Hu, X.; Liu, B.; Ma, Z.; Xu, Z. Failure mode analysis of post-seismic rockfall in shattered mountains exemplified by detailed investigation and numerical modelling. Landslides 2020, 18, 425-446. [CrossRef]

5. Iverson, R.M. Landslide triggering by rain infiltration. Water Resour. Res. 2000, 36, 1897-1910. [CrossRef]

6. Cui, Y.; Cheng, D.; Choi, C.E.; Jin, W.; Lei, Y.; Kargel, J.S. The cost of rapid and haphazard urbanization: Lessons learned from the Freetown landslide disaster. Landslides 2019, 16, 1167-1176. [CrossRef]

7. Iverson, R.M.; George, D.L. Modelling landslide liquefaction, mobility bifurcation and the dynamics of the 2014 Oso disaster. Géotechnique 2016, 66, 175-187. [CrossRef]

8. Yin, Y.P.; Cheng, Y.; Liang, J.; Wang, W. Heavy-rainfall-induced catastrophic rockslidedebris flow at Sanxicun, Dujiangyan, after the Wenchuan Ms 8.0 earthquake. Landslides 2015, 13, 9-23. [CrossRef]

9. Gao, Y.; Li, B.; Gao, H.; Chen, L.; Wang, Y. Dynamic characteristics of high-elevation and long-runout landslides in the Emeishan basalt area: A case study of the Shuicheng "7.23" landslide in Guizhou, China. Landslides 2020, 17, 1663-1677. [CrossRef]

10. Miyabuchi, Y.; Daimaru, H. The June 2001 rainfall-induced landslides and associated lahars at Aso volcano (southwestern Japan): Implications for hazard assessment. Acta Vulcanol. 2004, 16, 21.

11. Pánek, T.; Brázdil, R.; Klimeš, J.; Smolková, V.; Hradecký, J.; Zahradníček, P. Rainfall-induced landslide event of May 2010 in the eastern part of the Czech Republic. Landslides 2011, 8, 507-516. [CrossRef]

12. Yang, H.; Yang, T.; Zhang, S.; Zhao, F.; Hu, K.; Jiang, Y. Rainfall-induced landslides and debris flows in Mengdong Town, Yunnan Province, China. Landslides 2020, 17, 931-941. [CrossRef]

13. Tofani, V.; Segoni, S.; Agostini, A.; Catani, F.; Casagli, N. Technical note: Use of remote sensing for landslide studies in Europe. Nat. Hazards Earth Syst. Sci. 2013, 13, 1-12. [CrossRef]

14. Peternel, T.; Kumelj, S.; Ostir, K.; Komac, M. Monitoring the Potoška planina landslide (NW Slovenia) using UAV photogrammetry and tachymetric measurements. Landslides 2017, 14, 395-406. [CrossRef]

15. Niethammer, U.; James, M.R.; Rothmund, S.; Travelletti, J.; Joswig, M. UAV-based remote sensing of the Super-Sauze landslide: Evaluation and results. Eng. Geol. 2012, 128, 2-11. [CrossRef]

16. Prosdocimi, M.; Calligaro, S.; Sofia, G.; Fontana, G.D.; Tarolli, P. Bank erosion in agricultural drainage networks: New challenges from structure-from-motion photogrammetry for post-event analysis. Earth Surf Process. Landf. 2015, 40, 1891-1906. [CrossRef]

17. Huang, H.; Long, J.; Lin, H.; Zhang, L.; Yi, W.; Lei, B. Unmanned aerial vehicle based remote sensing method for monitoring a steep mountainous slope in the Three Gorges Reservoir, China. Earth Sci. Inform. 2017, 10, 287-301. [CrossRef]

18. Nevada, B. ContextCapture User Manual; Bentley Systems, Incorporated: Chester County, PA, USA, 2016.

19. Pix4D S.A. Pix4DCapture; Pix4D China Technology Co., Ltd.: Lausanne, Switzerland, 2018.

20. Peppa, M.V.; Mills, J.P.; Moore, P.; Miller, P.E.; Chambers, J.E. Brief communication: Landslide motion from cross correlation of UAV-derived morphological attributes. Nat. Hazards Earth Syst. Sci. 2017, 17, 2143-2150. [CrossRef]

21. He, K.; Ma, G.; Hu, X.; Liu, B. Failure mechanism and stability analysis of a reactivated landslide occurrence in Yanyuan City, China. Landslides 2020, 18, 1097-1114. [CrossRef]

22. Liu, B.; Hu, X.W.; He, K.; He, S.H.; Shi, H.B.; Liu, D.Y. The starting mechanism and movement process of the co-seismic rockslide: A case study of the Laoyingyan rockslide induced by the "5.12" Wenchuan earthquake. J. Mt. Sci. 2020, 17, 1188-1205. [CrossRef]

23. Xu, Q.; Peng, D.; Zhang, S.; Zhu, X.; He, C.; Qi, X.; Zhao, K.; Xiu, D.; Ju, N. Successful implementations of a real-time and intelligent early warning system for loess landslides on the Heifangtai terrace, China. Eng. Geol. 2020, 278, 105817. [CrossRef]

24. Ju, N.; Huang, J.; He, C.; Van Asch, T.; Huang, R.; Fan, X.; Xu, Q.; Xiao, Y.; Wang, J. Landslide early warning, case studies from Southwest China. Eng. Geol. 2020, 279, 105917. [CrossRef]

25. Allasia, P.; Godone, D.; Giordan, D.; Guenzi, D.; Lollino, G. Advances on Measuring Deep-Seated Ground Deformations Using Robotized Inclinometer System. Sensors 2020, 20, 3769. [CrossRef] [PubMed]

26. Crosetto, M.; Monserrat, O.; Luzi, G.; Cuevas-González, M.; Devanthéry, N. A noninterferometric procedure for deformation measurement using GB-SAR imagery. IEEE Geosci. Remote Sens. Lett. 2013, 11, 34-38. [CrossRef] 
27. Monserrat, O.; Crosetto, M.; Luzi, G. A review of ground-based sar interferometry for deformation measurement. ISPRS J. Photogramm. Remote Sens. 2014, 93, 40-48. [CrossRef]

28. Casagli, N.; Frodella, W.; Morelli, S.; Tofani, V.; Ciampalini, A.; Intrieri, E.; Raspini, F.; Rossi, G.; Tanteri, L.; Lu, P. Spaceborne, $\mathrm{UAV}$ and ground-based remote sensing techniques for landslide mapping, monitoring and early warning. Geoenvironmental Disasters 2017, 4, 9. [CrossRef]

29. Peduto, D.; Oricchio, L.; Nicodemo, G.; Crosetto, M.; Ripoll, J.; Buxó, P.; Janeras, M. Investigating the kinematics of the unstable slope of Barbera de la Conca (Catalonia, Spain) and the effects on the exposed facilities by GBSAR and multi-source conventional monitoring. Landslides 2021, 18, 457-469. [CrossRef]

30. Wang, L.; Yin, Y.; Huang, B.; Zhang, Z.; Wei, Y. Formation and characteristics of Guang'an village landslide in Wuxi, Chongqing, china. Landslides 2019, 16, 127-138. [CrossRef]

31. Fan, X.; Xu, Q.; Liu, J.; Subramanian, S.S.; He, C.; Zhu, X.; Zhou, L. Successful early warning and emergency response of a disastrous rockslide in Guizhou province, China. Landslides 2019, 16, 2445-2457. [CrossRef]

32. Carlà, T.; Tofani, V.; Lombardi, L.; Raspini, F.; Bianchini, S.; Bertolo, D.; Thuegaz, P.; Casagli, N. Combination of GNSS, satellite InSAR, and GB-InSAR remote sensing monitoring to improve the understanding of a large landslide in high alpine environment. Geomorphology 2019, 335, 62-75. [CrossRef]

33. Yang, H.; Liu, J.; Peng, J.; Wang, J.; Zhang, B. A method for GB-InSAR temporal analysis considering the atmospheric correlation in time series. Nat. Hazards 2020, 104, 1465-1480. [CrossRef]

34. Farina, P.; Coli, N.; Yön, R.; Eken, G.; Ketizmen, H. Efficient real time stability monitoring of mine walls: The çöllolar mine case study. In Proceedings of the International Mining Congress and Exhibition of Turkey, Antalya, Turkey, 16-19 April 2013; pp. 11-117.

35. Xu, Q. Understanding the landslide monitoring and early warning: Consideration to practical issues. J. Eng. Geol. 2020, 28, 175-189.

36. Hungr, O.; Evans, S.G. Entrainment of debris in rock avalanches: An analysis of a long run-out mechanism. Geol. Soc. Am. Bull. 2004, 116, 1240-1252. [CrossRef]

37. Zhang, S.-L.; Yin, Y.-P.; Hu, X.-W.; Wang, W.-P.; Zhang, N.; Zhu, S.-N.; Wang, L.-Q. Dynamics and emplacement mechanisms of the successive Baige landslides on the Upper Reaches of the Jinsha River, China. Eng. Geol. 2020, 278, 105819. [CrossRef]

38. McDougall, S.; Hungr, O. Dynamic modelling of entrainment in rapid landslides. Can. Geotech. J. 2005, 42, 1437-1448. [CrossRef]

39. Wang, W.; Yin, Y.; Zhu, S.; Wang, L.; Zhang, N.; Zhao, R. Investigation and numerical modeling of the overloading-induced catastrophic rockslide avalanche in Baige, Tibet, China. Bull. Int. Assoc. Eng. Geol. 2019, 79, 1765-1779. [CrossRef]

40. He, K.; Ma, G.; Hu, X.; Luo, G.; Mei, X.; Liu, B.; He, X. Characteristics and mechanisms of coupled road and rainfall-induced landslide in Sichuan China. Geomat. Nat. Hazards Risk 2019, 10, 2313-2329. [CrossRef]

41. Liu, B.; Hu, X.; Ma, G.; He, K.; Wu, M.; Liu, D. Back calculation and hazard prediction of a debris flow in Wenchuan meizoseismal area, China. B. Eng. Geol. Environ. 2021, 80, 3457-3474. [CrossRef]

42. Liu, B.; He, K.; Han, M.; Hu, X.; Wu, T.; Wu, M.; Ma, G. Dynamic process simulation of the Xiaogangjian rockslide occurred in shattered mountain based on 3DEC and DFN. Comput. Geotech. 2021, 134, 104122. [CrossRef] 